\title{
Pembangunan Piranti Lunak Pembantu Pemetaan Urusan Pemerintah Daerah
}

Development of Local Government Affairs Mapping Software

\author{
Anwar Fu'adi \\ Informatika, Fakultas Ilmu Rekayasa, Universitas Paramadina \\ Jl. Gatot Subroto Kav.97 Mampang Prapatan Jakarta Selatan 12790 \\ e-mail: anwar.fuadi@paramadina.ac.id
}

\begin{abstract}
Abstrak
Undang-Undang Republik Indonesia nomor 23 tahun 2014 tentang Pemerintahan Daerah mengamanatkan perubahan pembagian kewenangan untuk setiap urusan pemerintahan. Dengan demikian UU ini menuntut dilakukannya revisi Peraturan Pemerintah nomor 41 tahun 2007 tentang Organisasi Perangkat Daerah (PP41) dengan segera. Kemendagri harus mengkoordinasikan seluruh Kementrian dan Lembaga, serta seluruh pemerintah daerah untuk memetakan urusan pemerintahan yang akan digunakan sebagai dasar penyusunan pengganti PP41. Untuk memudahkan dan mempercepat proses penyusunan, Kemendagri memutuskan untuk menggunakan bantuan piranti lunak. Jurnal ini akan menyajikan hasil pembuatan piranti lunak dengan mengikuti kerangka generic software process yang meliputi communication, planning, modeling, construction, dan deployment. Bagian communication menyajikan kebutuhan pengguna terhadap piranti lunak. Bagian planning menyajikan perencanaan proyek dalam bentuk gantt chart. Bagian modeling menyajikan desain piranti lunak dalam bentuk UML. Bagian construction akan menyajikan platform pemrograman yang digunakan untuk memnganun piranti lunak. Bagian deployment akan menyajikan pemasangan piranti lunak pada infrastruktur yang disediakan oleh pengguna.
\end{abstract}

Kata kunci-UU23 2014, PP41 2007, generic software process

\section{Abstract}

Indonesian Constitution number 23 of 2014 about Local Government mandates a change in the distribution of authority for government affair. As an impact, Government Regulation number 41 of 2007(PP41) requires a revision immediately. The Ministry of Internal Affairs should coordinate with all other ministries ang agencies as well as all local government to map government affairs as a basis for composing PP41 replacement. To facilitate and accelerate the drafting process. The Ministry of Internal Affairs decided to use a software as an assistant. This journal will present the result of software creation by following the generic software process framework that includes communication, planning, modeling, construction, and deployment. Communication part present user requirement of the software. Planning part present the project planning is a gantt chart. Modeling part present the design of the software in UML format. Construction part present programming platform used to develop the software. Deployment part present software installation of the insfrastructure provided by the user.

Keywords- UU23 2014, PP41 2007, generic software process 


\section{PENDAHULUAN}

Undang-Undang RI Nomor 32 Tahun 2004 tentang Pemerintahan Daerah (UU 32) tidak sesuai lagi dengan perkembangan keadaan, ketatanegaraan, dan tuntutan penyelenggaraan pemerintahan daerah sehingga perlu diganti. Dengan dasar alasan tersebut maka diterbitkanlah Undang-Undang RI Nomor 23 Tahun 2014 tentang Pemerintahan Daerah(UU 23)[1].

UU 23 mengklasifikasi urusan pemerintahan ke dalam 3 jenis urusan yakni : Urusan Absolut, Urusan yang sepenuhnya menjadi kewenangan Pemerintah Pusat; Urusan Umum, Urusan yang menjadi kewenangan Presiden sebagai kepala pemerintahan; dan Urusan Konkuren, Urusan Pemerintahan yang kewenangannya dibagi antara Pemerintah Pusat, Pemerintah Daerah Provinsi, dan Pemerintah Daerah Kabupaten/Kota[1].

Urusan konkuren terdiri dari 32 bidang. Pada bagian lampiran dari UU 23, 32 bidang urusan konkuren tersebut di atas dibagi kembali ke dalam subbidang-subbidang. Kemudian dari setiap subbidang, pelaksanaan urusan secara jelas dibagi antara kewenangan pemerintah pusat, pemerintah daerah provinsi, dan pemerintah kabupaten/kota. Dalam pembagian kewenangan ini terdapat beberapa kewenangan yang berpindah. Sebagai contoh pada urusan pendidikan, kewenangan pengelolaan Sekolah Menengah Atas yang sebelumnya berada di wilayah kerja dinas pendidikan kabupaten/kota berpindah ke dinas pendidikan provinsi. Contoh lain pada urusan energi dan sumber daya mineral, penerbitan izin pemanfaatan panas bumi yang sebelumnya merupakan kewenangan provinsi berpindah menjadi kewenangan kabupaten/kota[1].

Dengan banyaknya perpindahan kewenangan ini maka amanat UU 23 tidak dapat langsung dijalankan. Untuk dapat menjalankan kewenangan-kewenangan yang baru maka perlu diadakan penyesuaian-penyesuaian pada organisasi perangkat daerah. Dalam hal ini, UU 23 juga mengamanatkan untuk mengklasifikasikan organisasi perangkat daerah menjadi tiga tipe yakni: Tipe A, dinas/badan dengan intensitas urusan besar; Tipe B, intensitas urusan sedang; Tipe C, intensitas urusan kecil.

Secara teknis, pengklasifikasian perangkat daerah belum diatur di UU 23. Dengan demikian diperlukan peraturan di bawah undang-undang untuk mengaturnya. Untuk hal-hal yang berkaitan dengan perangkat daerah, sebelumnya sudah diatur di dalam Peraturan Pemerintah Republik Indonesia Nomor 41 tahun 2007 tentang Organisasi Perangkat Daerah (PP 41). Atas dasar penyesuaian terhadap amanat UU 23, maka PP 41 harus direvisi dengan segera[2].

Perumusan revisi PP 41 yang nantinya menjadi acuan dalam perubahan struktur organisasi pemerintah daerah menjadi tanggung jawab Kementrian Dalam Negeri Republik Indonesia (Kemendagri). Namun dalam perumusan indikator-indikator yang akan digunakan untuk mengukur intensitas urusan di setiap daerah, Kemendagri harus berkoordinasi dengan seluruh Kementrian dan Lembaga (K/L) yang secara teknis menangani urusan-urusan yang termasuk ke dalam kelompok urusan konkuren[2].

Dalam perumusan revisi PP 41 dengan melibatkan seluruh K/L, Kemendagri memiki kendala-kendala yang yang harus dihadapi. Kendala-kendala tersebut antara lain:

1. Waktu. Revisi PP 41 harus selesai sebelum tahun 2016. Hal ini dikarenakan oleh amanat UU 23 yang harus mulai diundangkan maksimal 2 tahun setelah disahkan, yakni tahun 2016.

2. Keseragaman. Untuk memudahkan pemerintah daerah dalam menjalankan amanat UU 23 maupun peraturan pemerintah hasil revisi PP 41 maka seluruh K/L diharuskan menyusun indikator yang seragam.

3. Simulasi/Uji Publik. Sebelum dapat disahkan, revisi PP 41 harus terlebih dahulu di uji coba. Kemendagri membutuhkan gambaran organisasi perangkat daerah setelah mengikuti revisi PP 41.

Dengan alasan tersebut di atas, diputuskan untuk membangun sebuah piranti lunak $e$ government untuk membantu pelaksanaan pemetaan urusan pemerintah daerah. Hal ini sesuai 
dengan yang dikemukakan oleh Erick [3] bahwa penggunaan e-government dapat membantu menghindari maladministrasi dan meningkatkan kualitas layanan publik.

Piranti lunak ini akan digunakan oleh Kementerian Dalam Negeri untuk berkoordinasi dengan Kementerian dan Lembaga lain serta seluruh Pemerintah Daerah baik Kabupaten/Kota maupun Provinsi. Secara klasifikasi, jenis piranti lunak e-government ini termasuk dalam kategori aplikasi Government to Government [4]

\section{METODE PENELITIAN}

Penelitian ini bertujuan untuk membangun sebuah piranti lunak sesuai dengan kebutuhan pengguna. Oleh karena itu peneliti memilih menggunakan kerangka generic software process yang terdiri dari 5 tahap[5].

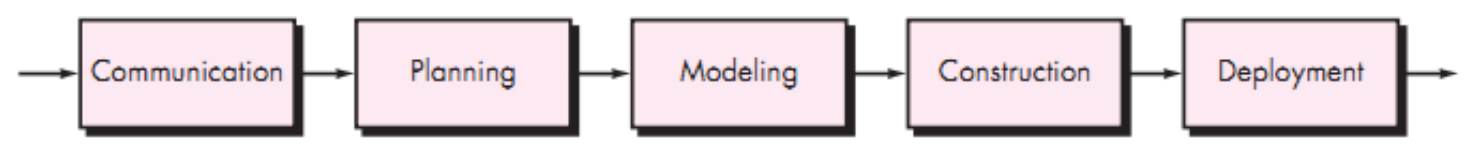

Gambar 1 Alur linear generic software process[5]

- Communication : Kolaborasi dan komunikasi dengan pengguna untuk memahami tujuan dan kebutuhan terhadap piranti lunak yang akan dibangun.

- Planning : Penyusunan rencana pengembangan piranti lunak yang berisi aktifitasaktifitas yang harus diselesaikan.

- Modeling : Pembuatan model yang bertujuan untuk pemahaman yang lebih baik terhadap kebutuhan dan acuan dalam mencapai kebutuhan tersebut

- Construction : Penyusunan kode program sebagai wujud dari piranti lunak

- Deployment : Penyerahan, pemasangan, dan evaluasi piranti lunak oleh pengembang kepada pengguna

\section{HASIL DAN PEMBAHASAN}

\subsection{Communication}

Fase communication dilakukan melalui berdiskusi dengan pengguna dari piranti lunak yang akan dibangun. Dalam hal ini pengguna diwakili oleh pejabat yang ada dilingkungan Direktorat Fasilitasi Kelembagaan dan Kepegawaian Perangkat Daerah, Direktorat Jendral Otonomi Daerah, Kementrian Dalam Negeri Republik Indonesia (FKKPD). Untuk menunjang identifikasi kebutuhan pengguna peneliti juga melakukan studi literatur terhadap peraturan perundangundangan terkait yakni UU 32, UU 23 dan PP 41.

Fase ini menghasilkan daftar kebutuhan pengguna sebagai berikut:

a. Piranti lunak memfasilitasi K/L melakukan pemetaan semua urusan yang ada di UU23 berikut juga urusan yang menunjang kegiatan pemerintah daerah

b. Pemetaan urusan dilakukan dengan menurunkan urusan, sub urusan, kewenangan, menjadi indikator besaran urusan

c. Seluruh indikator yang terindentifikasi disetiap urusan ditentukan skala dan bobotnya.

d. Antara satu daerah dan daerah yang lain memiliki beban pelaksanaan pekerjaan yang berbeda

e. Setiap pemerintah daerah dapat mengisikan nilai setiap indikator untuk daerahnya masing-masing

f. Piranti lunak mampu melakukan penghitungan nilai secara langsung berdasarkan indikator, skala, dan bobot

g. Piranti lunak mampu memperlihatkan secara langsung hasil pemetaan yang dilakukan dengan menunjukkan tipelogi perangkat daerah yang dapat dibentuk oleh pemerintah daerah 


\subsection{Planning}

Proyek pembangunan piranti lunak ini harus diselesaikan dalam waktu maksimal 3 bulan/12 minggu dengan mengikuti agenda berikut:

Tabel 1 Timeline proyek pembangunan piranti lunak pembantu pemetaan urusan pemda

\begin{tabular}{|l|l|l|l|l|l|l|l|l|l|l|l|l|l|}
\hline \multirow{2}{*}{ Agenda } & \multicolumn{3}{|l|}{ Bulan ke 1 } & \multicolumn{3}{|l|}{ Bulan ke 2 } & \multicolumn{3}{|c|}{ Bulan ke 3 } \\
\cline { 2 - 13 } & 1 & 2 & 3 & 4 & 1 & 2 & 3 & 4 & 1 & 2 & 3 & 4 \\
\hline Communication & & & & & & & & & & & & \\
\hline Planning & & & & & & & & & & & & \\
\hline Modeling & & & & & & & & & & & & \\
\hline Contruction & & & & & & & & & & & & \\
\hline Deployment & & & & & & & & & & & & \\
\hline
\end{tabular}

\subsection{Modeling}

Unified Modeling Language (UML) adalah bahasa pemodelan grafis untuk menggambarkan, mendeskripsikan, mengkonstruksikan, dan mendokumentasikan artifak-artifak dari sebuah sistem piranti lunak. UML dapat dijadikan sebagai sebuah standar untuk membuat blueprint sebuah sistem, yang mencakup hal-hal yang bersifat konseptual seperti proses bisnis dan fungsi-fungsi sistem, dan juga mencakup hal-hal yang bersifat konkrit seperti statemen bahasa pemrograman, skema basisdata, dan juga komponen sistem.

Di dalam spesifikasi UML terdapat 14 jenis diagram yang terbagi ke dalam dua jenis diagram yakni[6]:

1. Structural Modeling Diagrams : Package Diagrams, Comppnent Diagrams, Class Diagram, Deplyoment Diagram, Composite Structure Diagrams, Object Diagrams, Profile Diagrams

2. Behavioral Modeling Diagram: Use Case Diagram, Sequence Diagrams, Activity Diagrams, Timing Diagrams, State Machine Diagram, Interactions Overview Diagram, Communication Diagrams

\subsection{Analisa Sistem}

Urusan konkuren yang menjadi tanggung jawab pemerintah daerah terdiri dari 32 bidang. 32 bidang ini dibagi menjadi tiga kelompok yakni :

\subsubsection{Urusan wajib terkait dengan pelayanan dasar}

Yakni: pendidikan, kesehatan, pekerjaan umum dan penataan ruang, perumahan rakyat dan kawasan permukiman, ketenteraman ketertiban umum dan pelindungan masyarakat, sosial.

3.4.2. Urusan wajib tidak terkait dengan pelayanan dasar

Yakni: tenaga kerja, pemberdayaan perempuan dan pelindungan anak, pangan, pertanahan, lingkungan hidup, administrasi kependudukan dan pencatatan sipil, pemberdayaan masyarakat dan Desa, pengendalian penduduk dan keluarga berencana, perhubungan, komunikasi dan informatika, koperasi usaha kecil dan menengah, penanaman modal, kepemudaan dan olah raga, statistik, persandian, kebudayaan, perpustakaan, kearsipan

\subsubsection{Urusan pilihan}

Yakni: kelautan dan perikanan, pariwisata, pertanian, kehutanan, energi dan sumber daya mineral, perdagangan, perindustrian, transmigrasi. 
Setiap bidang tersebut di atas memiliki subbidang, dan setiap subbidang terdiri dari kewenangan-kewenangan yang terbagi antara pemerintah pusat, pemerintah daerah provinsi dan pemerintah kabupaten/kota. Berikut adalah contoh pembagian kewenangan pada bidang pendidikan:

Tabel 2 Pembagian kewenangan urusan pemerintahan bidang pendidikan

\begin{tabular}{|c|c|c|c|c|}
\hline No & SUB BIDANG & PEMERINTAH PUSAT & DAERAH PROVINSI & $\begin{array}{c}\text { DAERAH } \\
\text { KABUPATEN/KOTA }\end{array}$ \\
\hline 1 & 2 & 3 & 4 & 5 \\
\hline 1. & Manajemen Pendidikan & $\begin{array}{l}\text { a. Penetapan standar } \\
\text { nasional pendidikan. } \\
\text { b. Pengelolaan pendidikan } \\
\text { tinggi. }\end{array}$ & $\begin{array}{ll}\text { a. Pengelolaan } & \text { pendidikan } \\
\text { menengah. } & \\
\text { b. Pengelolaan } & \text { pendidikan } \\
\text { khusus. } & \end{array}$ & $\begin{array}{l}\text { a. Pengelolaan pendidikan } \\
\text { dasar. } \\
\text { b. Pengelolaan pendidikan } \\
\text { anak usia dini dan } \\
\text { pendidikan nofformal. }\end{array}$ \\
\hline 2. & Kurikulum & $\begin{array}{lr}\text { Penetapan } & \text { kurikulum } \\
\text { nasional } & \text { pendidikan } \\
\text { menengah, } & \text { pendidikan } \\
\text { dasar, pendidikan anak usia } \\
\text { dini, dan } & \text { pendidikan } \\
\text { nonformal. } & \\
\end{array}$ & $\begin{array}{l}\text { Penetapan kurikulum muatan } \\
\text { lokal pendidikan menengah } \\
\text { dan muatan lokal pendidikan } \\
\text { khusus. }\end{array}$ & 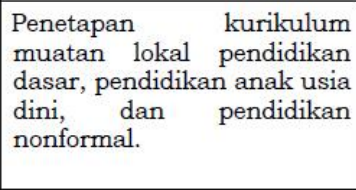 \\
\hline 3. & Akreditasi & $\begin{array}{l}\text { Akreditasi perguruan tinggi, } \\
\text { pendidikan menengah, } \\
\text { pendidikan dasar, } \\
\text { pendidikan anak usia dini, } \\
\text { dan pendidikan nonformal. }\end{array}$ & --- & --- \\
\hline 4. & $\begin{array}{l}\text { Pendidik dan Tenaga } \\
\text { Kependidikan }\end{array}$ & 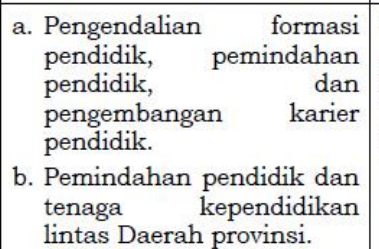 & \begin{tabular}{lllr} 
Pemindahan & pendidik & dan \\
tenaga & kependidikan & lintas \\
Daerah & \multicolumn{3}{c}{ kabupaten $/$ kota } \\
dalam & 1 & (satu) & Daerah \\
provinsi. & &
\end{tabular} & $\begin{array}{l}\text { Pemindahan pendidik dan } \\
\text { tenaga kependidikan dalam } \\
\text { Daerah kabupaten/kota. }\end{array}$ \\
\hline
\end{tabular}

Berdasarkan kewenangan-kewenangan yang sudah jelas dibagi oleh undang-undang, setiap kementrian teknis yang membawahi urusan tersebut harus merumuskan fungsi dasarnya. Fungsi dasar adalah aktifitas yang harus dijalankan untuk memberikan layanan terkait kewenangan yang dimiliki. Untuk selanjutnya setiap fungsi dasar ditentukan indikator teknisnya. Indikator adalah variabel pembentuk beban yang mempengaruhi kebutuhan sumber daya untuk memberikan layanan. Berikut adalah contoh perumusannya:

Tabel 3 Contoh perumusan fungsi dasar dan indikator

\begin{tabular}{|c|c|c|}
\hline Kewenangan & Fungsi Dasar & Indikator \\
\hline $\begin{array}{l}\text { Pengelolaan } \\
\text { menengah }\end{array}$ & $\begin{array}{l}\text { Mengelola administrasi } \\
\text { pendidikan menengah }\end{array}$ & $\begin{array}{l}\text { Jumlah anak usia } \\
\text { pendidikan menengah }\end{array}$ \\
\hline $\begin{array}{l}\text { Pengelolaan } \\
\text { khusus. }\end{array}$ & $\begin{array}{l}\text { Mengelola administrasi } \\
\text { pendidikan khusus }\end{array}$ & $\begin{array}{l}\text { Jumlah anak usia sekolah } \\
\text { berkebutuhan khusus }\end{array}$ \\
\hline \multirow{2}{*}{$\begin{array}{l}\text { Penetapan kurikulum } \\
\text { muatan lokal pendidikan } \\
\text { menengah dan muatan } \\
\text { lokal pendidikan khusus. }\end{array}$} & $\begin{array}{l}\text { Menetapkan kurikulum muatan } \\
\text { lokal pendidikan menengah }\end{array}$ & \multirow{2}{*}{$\begin{array}{l}\text { Jumlah kurikulum muatan } \\
\text { lokal pendidikan menengah } \\
\text { dan pendidikan khusus }\end{array}$} \\
\hline & $\begin{array}{l}\text { Menetapkan kurikulum muatan } \\
\text { lokal pendidikan khusus }\end{array}$ & \\
\hline $\begin{array}{l}\text { Penerbitan izin pendidikan } \\
\text { menengah } \quad \text { yang }\end{array}$ & $\begin{array}{l}\text { Menerbitkan izin pendidikan } \\
\text { menengah yang diselenggarakan }\end{array}$ & $\begin{array}{l}\text { Jumlah satuan pendidikan } \\
\text { menengah dan pendidikan }\end{array}$ \\
\hline $\begin{array}{l}\text { diselenggarakan oleh } \\
\text { masyarakat }\end{array}$ & $\begin{array}{l}\text { oleh masyarakat (sekolah } \\
\text { swasta) }\end{array}$ & $\begin{array}{lr}\text { khusus } & \text { yang } \\
\text { diselenggarakan } & \text { oleh } \\
\text { masyarakat } & \end{array}$ \\
\hline
\end{tabular}


Tahapan perumusan selanjutnya adalah pemberian bobot untuk setiap indikator. Total bobot yang dibagi harus $100 \%$. Berikut adalah contoh pembobotannya:

Tabel 4 Contoh pembobotan indikator

\begin{tabular}{|l|l|}
\hline Indikator & Bobot \\
\hline Jumlah anak usia pendidikan menengah & $10 \%$ \\
\hline Jumlah anak usia sekolah berkebutuhan khusus & $10 \%$ \\
\hline $\begin{array}{l}\text { Jumlah kurikulum muatan lokal pendidikan menengah dan pendidikan } \\
\text { khusus }\end{array}$ & $25 \%$ \\
\hline $\begin{array}{l}\text { Jumlah satuan pendidikan menengah dan pendidikan khusus yang } \\
\text { diselenggarakan oleh masyarakat }\end{array}$ & $15 \%$ \\
\hline$\ldots$ indikator lain... & $40 \%$ \\
\hline TOTAL & $\mathbf{1 0 0 \%}$ \\
\hline
\end{tabular}

Selain bobot, setiap indikator juga dirumuskan interval dan skalanya. Berikut adalah contoh interval dan skala untuk satu indikator.

Tabel 5 Contoh perumusan interval

\begin{tabular}{|l|l|l|}
\hline Indikator & Interval & Skala \\
\hline \multirow{3}{*}{$\begin{array}{l}\text { Jumlah anak usia pendidikan } \\
\text { mengah }\end{array}$} & $<30.000$ & 200 \\
\cline { 2 - 3 } & $30.000-40.000$ & 400 \\
\cline { 2 - 3 } & $40.001-50.000$ & 600 \\
\cline { 2 - 3 } & $50.001-60.000$ & 800 \\
\cline { 3 - 3 } & $>60.000$ & 1000 \\
\hline
\end{tabular}

Setelah sebuah bidang urusan selesai dirumuskan indikator, bobot, interval, dan skalanya, Proses selanjutnya adalah proses pengisian nilai indikator oleh seluruh pemerintah daerah. Sebagai contoh perhitungan, misalkan di Provinsi Kalimantan Timur jumlah anak usia pendidikan menengah adalah 55.000 anak, maka perhitungan skornya adalah sebagai berikut :

Tabel 6 Contoh penghitungan skor

\begin{tabular}{|c|c|c|c|c|c|}
\hline Indikator & Bobot & Nilai & Interval & Skala & Skor \\
\hline 1 & 2 & 3 & 4 & 5 & $6=2 \times 5$ \\
\hline $\begin{array}{l}\text { Jumlah anak usia } \\
\text { pendidikan menengah }\end{array}$ & $10 \%$ & 55.000 & $50.001-60.000$ & 800 & $\begin{array}{l}10 \% \times 800= \\
80\end{array}$ \\
\hline indikator lain... & $90 \%$ & $\ldots$ & $\ldots$ & $\ldots$ & 700 \\
\hline \multicolumn{5}{|l|}{ Total Skor } & 780 \\
\hline \multicolumn{5}{|l|}{ Faktor Pengali Wilayah } & 1,1 \\
\hline \multicolumn{5}{|l|}{ Total Skor Akhir } & 858 \\
\hline
\end{tabular}

Setelah total skor diketahui maka selanjutnya total skor harus dikalikan dengan faktor pengali wilayah. Faktor pengali wilayah ini digunakan untuk memberikan keadilan antar wilayah. Melakukan pekerjaan administrasi di wilayah pulau kalimantan pasti lebih berat dari pada melakukan pekerjaan administrasi di pulau jawa. Begitu juga, melakukan pekerjaan administrasi di wilayah kepulauan pasti lebih berat dari pada di kalimantan. Dengan dasar ini maka setiap wilayah memiliki faktor pengali yang berbeda. Misalnya: 
Tabel 7 Contoh faktor pengali wiayah

\begin{tabular}{|l|l|}
\hline Wilayah & Pengali \\
\hline Jawa & 1 \\
\hline Kalimantan \& Sumatera & 1,1 \\
\hline Kepulauan & 1,2 \\
\hline
\end{tabular}

Selain merumuskan indiikator, kementrian teknis juga harus merumuskan klasifikasi dinas. Sesuai dengan amanat UU 23, klasifikasi dinas terdiri dari tiga tingkatan yakni Dinas Tipe A, Dinas Tipe B, Dinas Tipe C. Berikut adalah contoh perumusan klasifikasi dinas.

Tabel 8 Contoh klasifikasi tipe dinas berdasar skor

\begin{tabular}{|l|l|}
\hline Tipe Dinas & Skor \\
\hline Dinas Pendidikan Provinsi Tipe C & $0-500$ \\
\hline Dinas Pendidikan Provinsi Tipe B & $501-750$ \\
\hline Dinas Pendidikan Provinsi Tipe A & $>751$ \\
\hline
\end{tabular}

Dengan demikian setelah diketahui skor urusan bidang pendidikan di Kalimantan Timur adalah 858, dapat disimpulkan bahwa di Provinsi Kalimantan Timur perlu dibentuk Dinas Pendidikan dengan Tipe A. Untuk selanjutnya Provinsi Kalimantan Timur tinggal mengikuti ketentuan yang berlaku mengenahi pembentukan Dinas Pendidikan Tipe A.

\subsection{Diagram UML}

Berdasarkan analisa sistem di atas, maka dengan menggunakan use case diagram, kebutuhan pengguna piranti lunak yang akan dikembangkan dapat digambarkan sebagai berikut:

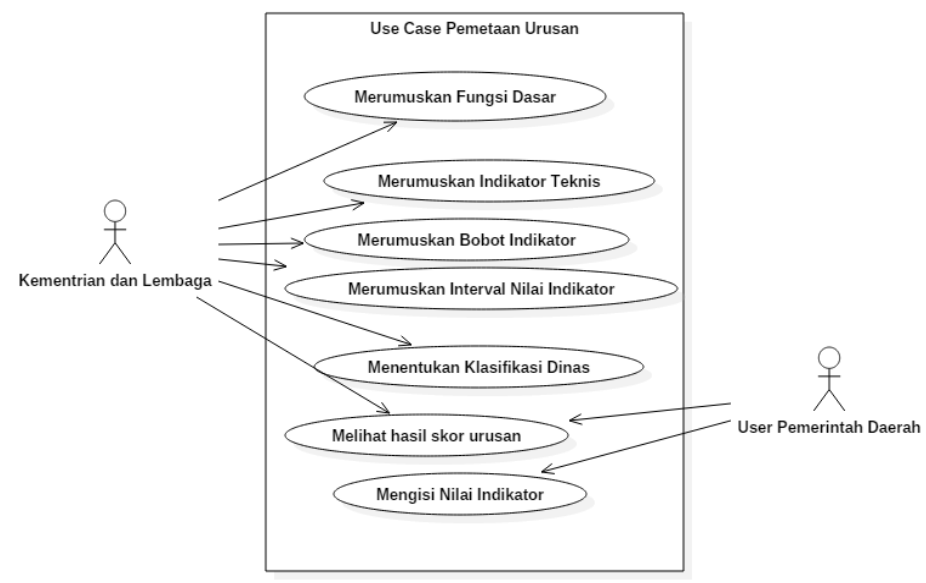

Gambar 2 Use Case Diagram

Dari diagram use case di atas, dapat dilihat bahwa piranti lunak akan digunakan oleh dua jenis pengguna yakni pengguna dari K/L, dan Pemerintah Daerah. Pengguna dari K/L akan menggunakannya untuk keperluan perumusan dan melihat hasil, sedangkan user pemerintah daerah akan menggunakan piranti lunak untuk memasukkan nilai indikator-indikator dan melihat hasil. 
Aktifitas perumusan yang dilakukan oleh pengguna dari K/L digambarkan dalam activity diagram berikut:

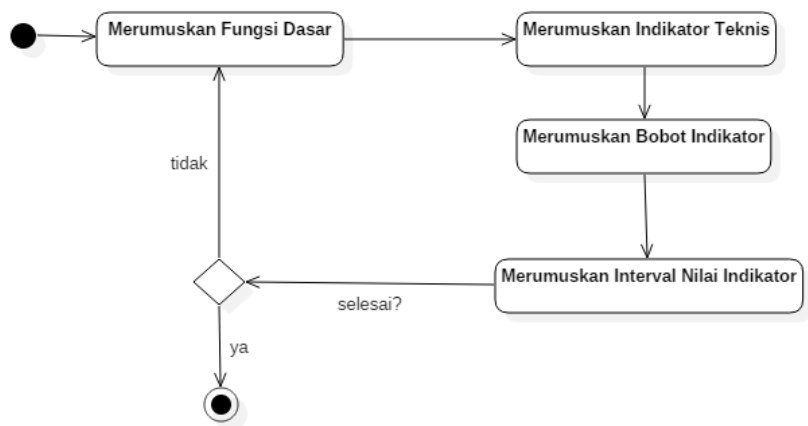

Gambar 3 Activity Diagram 1

Aktivitas pengisian nilai indikator yang dilakukan oleh pengguna dari pemerintah daerah digambarkan dalam activity diagram berikut:

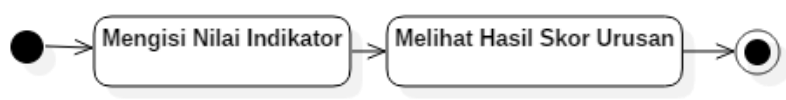

\section{Gambar 4 Activity Diagram 2}

Setelah pengguna-pengguna dari pemerintah daerah memasukkan nilai indikator-indikator, pengguna dari $\mathrm{K} / \mathrm{L}$ dapat melihat hasil dari pemetaan urusan untuk seluruh pemerintah daerah. Proses ini merupakan proses uji publik sebelum indikator, bobot, interval, dan klasifikasi disahkan sebagai lampiran di dalam pengganti PP 41. K/L akan mengevaluasi apakah hasil pemetaan sudah sesuai. Jika belum maka K/L dapat mengubah nilai-nilai pada bobot, interval, dan klasifikasi dinas hingga hasil pemetaan menjadi sesuai.

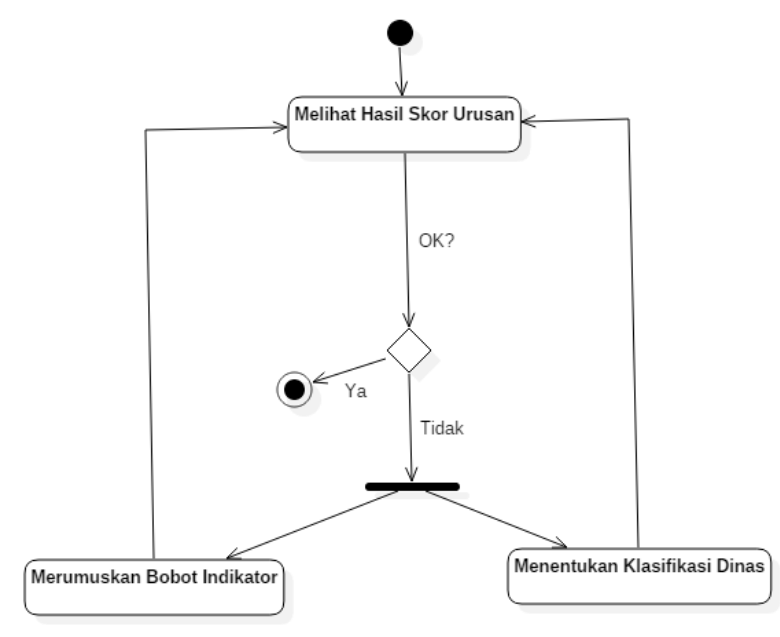

Gambar 5 Activity Diagram 3

Dalam pemrograman berorientasi objek, Kelas-kelas yang dibutuhkan untuk membangun piranti lunak ini tergambarkan dalam class diagram berikut: 


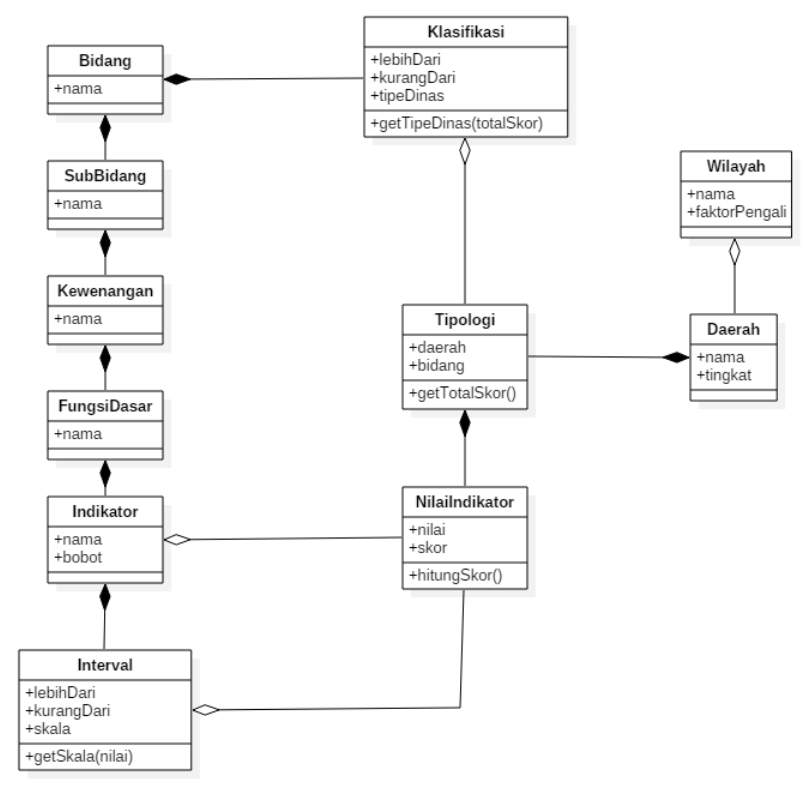

Gambar 6 Class Diagram

Fungsi-fungsi utama dalam penghitungan skor dan perolehan hasil pemetaan akhir digambarkan dalam dua sequence diagram berikut:

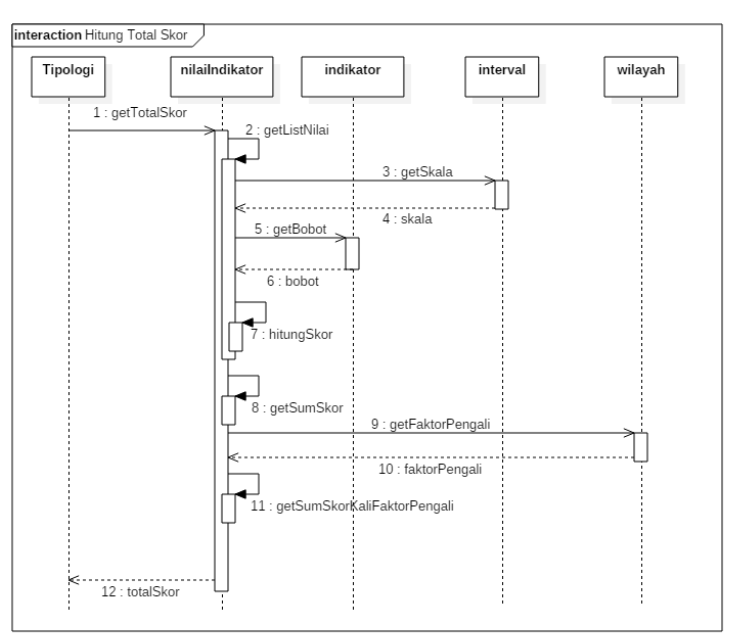

Gambar 7 Sequence Diagram 1

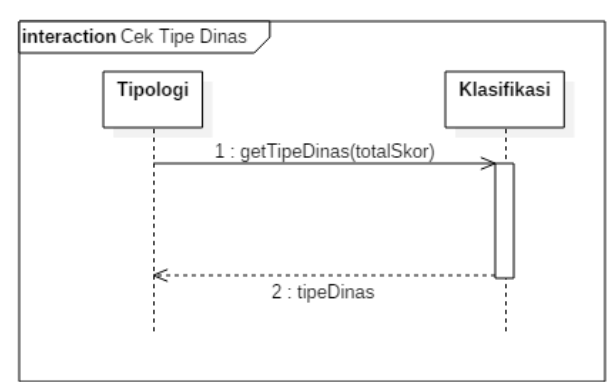

Gambar 8 Sequence Diagram 1

\subsection{Contruction}

Fase contruction terbagi menjadi dua yakni pembuatan basis data dan coding. Basis data yang digunakan untuk piranti lunak ini adalah MySQL 5. Berdasarkan modeling yang telah dilakukan skema basisdata yang dibangun adalah sebagai berikut: 


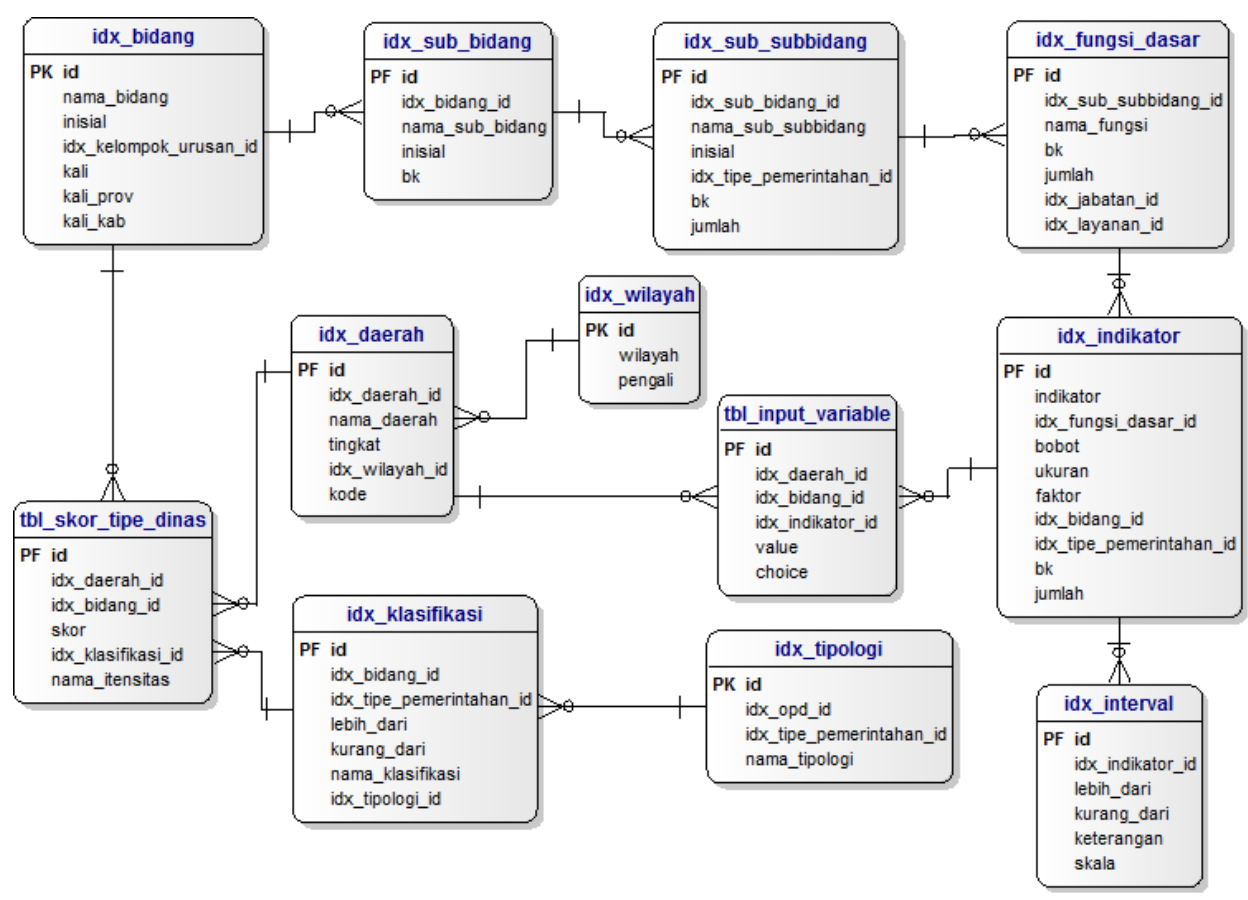

\section{Gambar 9 ERD Skema Basis Data}

Coding piranti lunak dilakukan dengan menggunakan framework pemrograman Prado. Prado adalah framework bahasa pemrograman PHP5 berbasis komponen yang dapat digunakan untuk membangun piranti lunak berbasis web dengan cepat. Prado melakukan konseptualisasi pembangunan piranti lunak berdasarkan komponen, even, dan properti. Berikut adalah salah satu contoh realisasi dari coding piranti lunak ini dengan menggunakan framework prado.

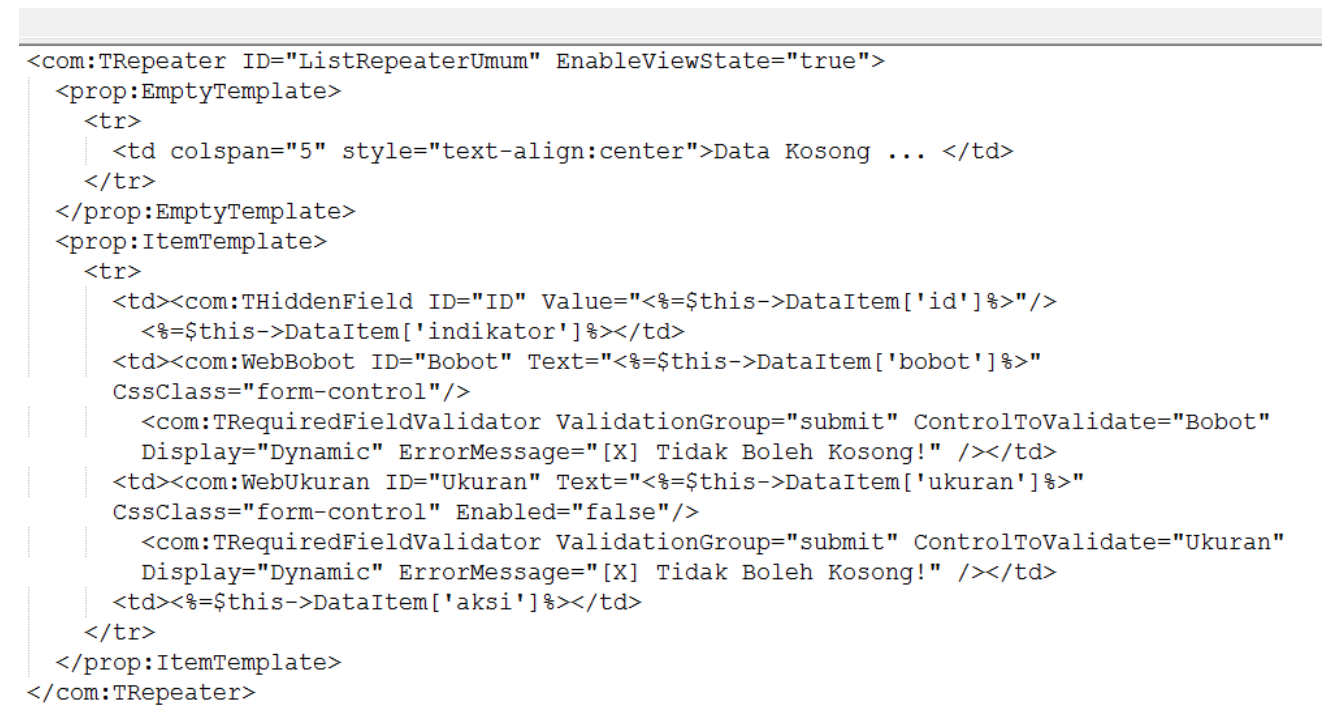

Gambar 10 Konseptualisasi objek tabel dalam bentuk komponen TRepeater 


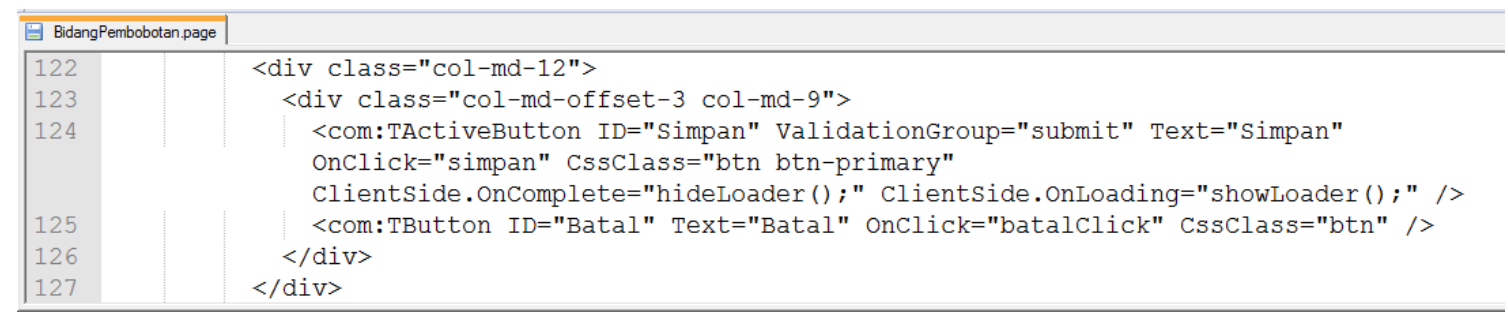

Gambar 11 Konseptualisasi objek dalam bentuk even dan properti OnClick

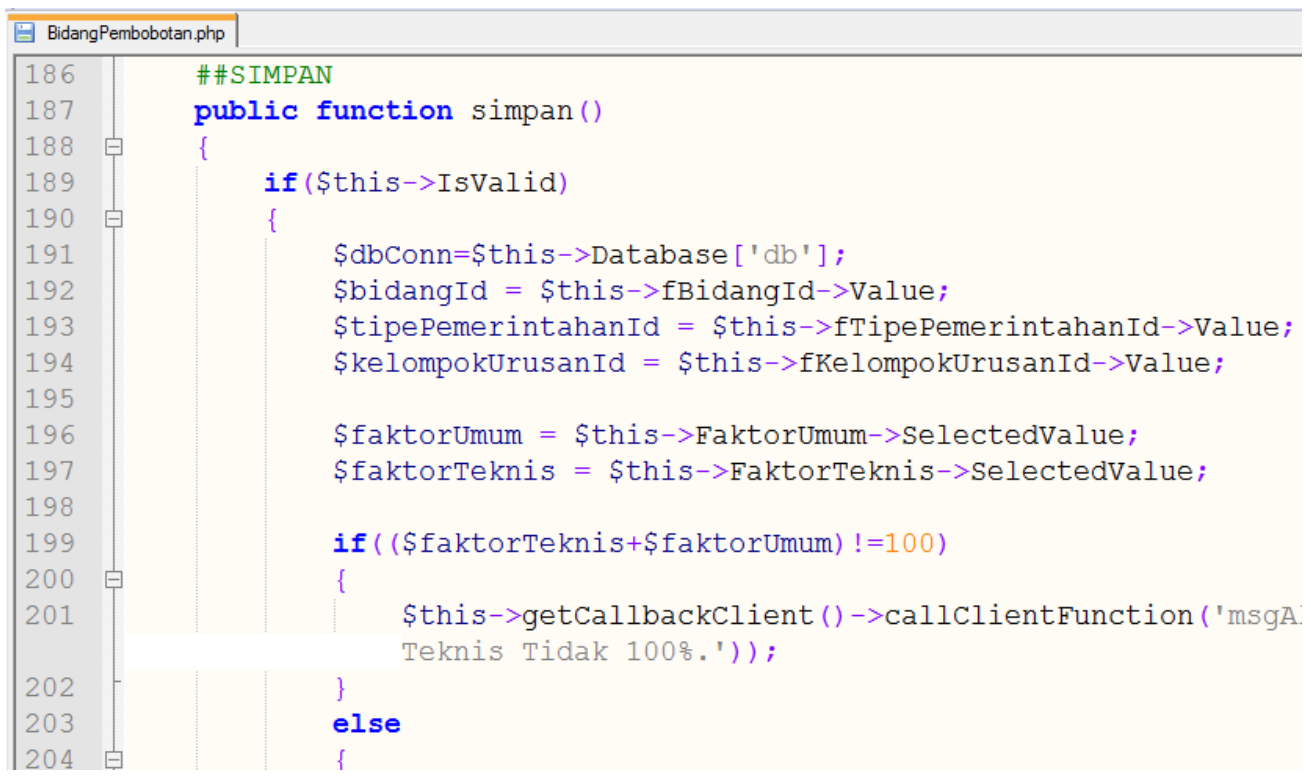

Gambar 12 Fungsi untuk merima perintah dari even OnClick

\subsection{Deployment}

Setelah piranti lunak selesai dibangun, fase selanjutnya yang dilakukan adalah deployment. Dalam fase deployment piranti lunak dipasang pada infrastruktur yang disiapkan oleh pengguna dan diperasionalkan. Berikut adalah diagram deployment yang menggambarkan bagaimana piranti lunak ini dipasang.

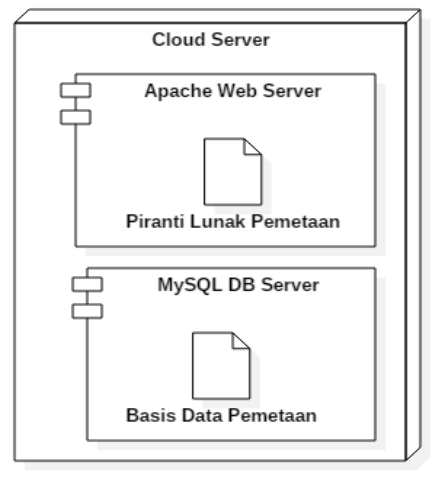

Gambar 13 Deployment Diagram Piranti Lunak Pemetaan Urusan Pemda

Selanjutnya piranti lunak ini dapat diakses melalui tautan : http://fasilitasi.otda.kemendagri.go.id 


\section{KESIMPULAN}

Dari penelitian ini dihasilkan piranti lunak akan dimanfaatkan oleh FKKPD untuk memfasilitasi K/L dan Pemerintah daerah dalam melakukan pemetaan urusan sesuai dengan amanat UU23. Dengan piranti lunak ini diharapkan proses pemetaan urusan akan menjadi cepat, seragam, dan terkoordinasikan dengan baik sehingga dapat dijadikan acuan uji publik sebelum hasilnya ditetapkan dalam sebuah Peeraturan Pemerintah.

\section{SARAN}

Dalam tahapan communication peneliti mengidentifikasi bahwa piranti lunak ini dapat dikembangkan lebih lanjut sebagai alat bantu pengelolaan kelembagaan dan kepegawaian pemerintah daerah. Dengan demikian peneliti mensarankan pengembangan piranti lunak ini lebih lanjut ke arah tersebut.

\section{DAFTAR PUSTAKA}

[1] Republik Indonesia, 2014. Undang-Undang Republik Indonesia Nomor 23 Tahun 2014 Tentang Pemerintahan Daerah. Kemenkumham, Jakarta.

[2] Republik Indonesia, 2007, Peraturan Pemerintah Republik Indonesia nomer 41 tahun 2007 tentang Organisasi Pemerintah Daerah. Kemenkumham, Jakarta.

[3] Errick, S., Holle, 2011, Pelayanan Publik Melalui Elektronik Government: Upaya Meminimalisir Praktek Maladministrasi Dalam Meningkatkan Public Service, Jurnal Sasi, Vol 17, hal 21-30

[4] Zainal, A., Hasibuan, and Harry, B., Santoso, 2005, Standardisasi Aplikasi E-Government Untuk Instansi Pemerintah, Prosiding Konferensi Nasional Teknologi Informasi dan Komunikasi Indonesia ITB, hal 42-48

[5] Pressman, Roger S, 2010, Software engineering : a practitioner's approach, Ed.7, McGrawHill, New York.

[6] Sparx, t.thn, UML 2 Tutorial, http://www.sparxsystems.com/resources/uml2_tutorial/, diakses tgl 18 Agustus 2017 